REPORTS OF MORPHOLOGY
Official Journal of the Scientific Society of Anatomists,
Histologists, Embryologists and Topographic Anatomists
of Ukraine
journal homepage: https://morphology-journal.com

\title{
Morphological condition of the pulp of intact and affected by caries third molars
}

\author{
Kostylenko Y.P., Talash R.V., Bilash S.M., Boyko I.V., Bukhanchenko O.P., Ivanytska O.S.
}

Ukrainian Medical Stomatological Academy, Poltava, Ukraine

\section{ARTICLE INFO}

Received: 3 September, 2020

Accepted: 12 October, 2020

UDC: $616.314 .18 . / 8-002.4-091$

CORRESPONDING AUTHOR

e-mail: viktorya.talash@gmail.com Talash R.V.
To date, there is a theory that increased resistance to caries is observed in the teeth, which for any reason underwent destructive changes in the pulp. That is why there is a need to study the impact of pulp vitality on the development of the carious process. The aim of the research was to study the microscopic structure of epoxy sections of intact and carious third molars. We studied 4 intact and 6 carious third molars. For this purpose, specimens were made taking into account the free penetration of the fixative solution into the pulp. To this end, immediately after the tooth was removed, we cut off its roots almost near the crown, preserving the integrity of the latter. The method relied on the impregnation of specimens with epoxy resin, according to the method of epoxy plastination of tooth specimens, developed at the Department of Human Anatomy of Ukrainian Medical Stomatological Academy. The epoxy blocks were cut with a disk into two halves until the hard tissues of the tooth crown were exposed together with the pulp. We found that the hard tissues (dentin and enamel coating) of intact third molars did not have any structural defects. However, their pulp chamber contained mainly an amorphous substance, devoid of any typical pulp tissue structures. That is, the pulp was in a state of complete devolution. Quite the opposite presentation was observed in specimens of carious teeth. We found that their pulp chamber contained quite noticeable tissue structures typical of the dental pulp. It is interesting that in the subodontoblastic layer, in front of the carious alteration of the enamel, there was compaction of the pulp, which may be due to infiltration of perivascular connective tissue by immunocompetent cells. It was found that on the border with carious destruction of enamel, there was a compacted spot of altered dentin, whose matrix was intensely pigmented in brown colour, due to the accumulation of melanin on the dentino-enamel junction. Its excessive formation is associated with the destruction of protein-carbohydrate complexes of organic matter in the deep layers of dentin. We found that the pulp compaction and the focus of carious alteration of the enamel are projectively connected by a radial cord of altered dentin, known in the literature as "dead tracts". Hence, there is reason to believe that the identified changes indicate a latent form of caries, with a pulpogenic mechanism of development. Thus, it can be argued that the teeth, which for any reason underwent degenerative changes in the pulp, are not prone to carious lesions, whereas in carious teeth, the pulp is active and involved in the pathogenesis of the carious process. Keywords: caries, third molars, epoxy thin section, enamel, dentine, pulp.

\section{Introduction}

Today, the existent theory of the exogenous nature of caries has not brought its correctness $[6,7,8,9,10,13,18$, $21,23,25,28]$. Thus, it is created a lot of contradictions, the main of them are the next facts that we find in the modern scientific literature $[2,5,14,21,33]$. They testify about the pulpogenic mechanism of the development of caries:

1. Discovery of subenamel caries and also retrograde (centered) its progress.
2. The hard tissues of the tooth which were left after carious necrosis of the pulp cannot be damaged by caries.

3. Cases of carious damage of the enamel-dentine area while the saving of integrity of the superficial enamel.

4. Caries has damaged the retained third molars.

More clear and principal new conception which opposite to the exogenic theory of caries, were proposed and substantiated theoretically Yu.P. Kostylenko and I.V. Boiko [21]. 
Authors noticed that organic structures of enamel, which are located in the border with dentine, have immunological properties and enamel is considered as "unbarrier" tissue which lets to consider the problem in the view of the theory about mechanisms of the damage of the immunological toleration. While, the source of the primaries sensitization can be both primary, natural and acquired, secondary autoantigens occur in the fissured areas of the teeth, under the influence of some physicochemical or infectious factors (theory of altered antigens) [15, 21]. In the works of many authors $[5,6,9,17,26,27,29]$ were proved that damage of enamel occurs as a result of immune reaction in the tooth pulp. This conclusion was based that different affections of the dental system are related to any unfavorable condition of the organisms, are beginning of the pulp. Thus, degenerative changes in it during chronic rheumatic disease, endocrine disorders, infection disease, avitaminosis, toxicosis of pregnancy, etc. can be noticed when changes in the hard tissues had not been found yet.

That is enough for making a general conclusion: increasing of the stability to caries was observed in the teeth from various causes were took place destructive changes in the pulp while the teeth were isolated from the oral cavity and did not protect from carious damage of the hard tissues. Thus, we have reasons to consider the vital activity of the pulp as an indirect link in the development of carious process. But it should be taken into account, that this thesis has not proved yet, because the direct research in the literature is missing today. That is why we have tried to use opportunities which were received during the study of the individual diversity of third molars that may be got in the clinic during the extraction of the teeth in different clinical indication.

The aim of the research: the study of the microscopic structure of the epoxy sections of the intact and damaged by caries third molars.

\section{Material and methods}

Connection of the study with planned scientific research works. This work is fragment of scientific research work "Age aspects of structural organization of immune system organs, glands of gastrointestinal tracts and urogenital system of human in norm and pathology", state registration № 0116 U004192.

Four intact (crown without visible external damaged by caries) and six third molars with damage by caries, that were received from the Department of Oral and Maxillofacial Surgery with Plastic and Reconstructive Surgery of the Head and Neck of UMSA were studied.

In the view of methodical feature of our research, that includes the study of hard tissues of teeth with their pulps, we had to take measures for prevention of pulp destroy in process of preparation of necessary prepares. For this, it was necessary to create ability for free penetration of fixative solution into the pulp. In this purpose, immediately after extraction and visual assessment of tooth, we cut its root off on level of crown, care about saving of one's integrity. After this, it was washed for a short time by warm $\left(\mathrm{t}-37^{\circ} \mathrm{C}\right)$ saline and plunged into bottle with $10 \%$ solution of neutral formalin.

After three-day fixation, received prepares washed from formalin away under running water, and they were dehydrated by spirit of incising concentration with the gradual transition to pure acetone according to our method [20, 22]. According to it, further procedure consisted in impregnation of epoxy resin. In this purpose, we used epoxy glue "Chimcontact-Epoxy". The final stage was moving prepares into appropriate for size ditches and filling them by freshly made epoxy resin.

After polymerization, received epoxy blocs were cut by disk for separation into two halves in necessary plane of intersection, which caused baring (on the end surfaces of the two halves) of hard tissues of tooth crown with pulp. It was found, that pulp of these teeth was impregnated by hardened epoxy resin.

The next stage in preparation of prepares for microscopic research was creation of polished epoxy sections that were carried out manually with sandpaper by alternatively changing it in decreasing order of the degree of abrasiveness. After this, these prepares can be studied by light microscope. However, excepting of Hunter-Schreger enamel strips, it was impossible to see any microscopic details. Besides, in this aspect tissue structure of the tooth on the section were unapproachable for reaction with according coloring because their organic components were hidden in the vast majority of minerals. Therefore, for get rid of them we subjected epoxy sections to superficial digestion (decalcification) in chelating agent - Trilon B. Necessity of fixation of hard tissues of tooth in epoxy resin becomes clear from it. It plays as a limiter for the directed action of the decalcifying solution in the section. It is possible only during the grinding of surface of hard tissues of tooth. After this procedure even uncolored sections permit to visualize their structure more clearly than those we used in some cases. However, full information we can receive only after coloring of epoxy section by $1 \%$ solution of methylene blue on $1 \%$ solution of borax.

Study and photo documentation of prepares were carried out by binocular magnifying glass MBS- 9 equipped with camera at different magnifications.

Conducted research replies moral-ethical norms and basic principles of Council of Europe Convection on Human Rights and Biomedicine and relevant legislative documents of Ukraine. The Commission on Bioethics of VDNZU "Ukrainian Medical Stomatological Academy" (protocol №160 dated 14.12.2017 did not reveal any violations of moral and ethical norms during the research work.

There was no special need for the application of parametric statistical analysis, because the changes in the microscopic structure of the third molars obtained by us did not differ significantly. 


\section{Results}

Figure 1 shows microphoto of crown department of two intact third molars on the same magnification. It attracts attention, that their enamel coating has no destructive defects. Due to surface decalcification and coloring by methylene blue, the Hunter-Schreger bands, which essentially nodal bundle0like chains of crystal fibers, became clearly visible. Dentyne was without any visible alterative changes, in it the radial stripe was clearly visible due to typical orientation of dentinal tubules. Along with this, the content of the pulp chamber was mainly amorphous substance with no signs of the presence of such typical pulp tissues structures as: connective tissues elements, blood microvessels, nerve fibers and odontoblasts. Only ones formations that were clearly manifested were pathological deposits in the form of denticles and various forms of petrifaction. Notable that most often they were in the area of the horns of the pulp chamber (Fig. 1).

Quite the opposite picture is presented by prepares of carious third molars with stored pulp in them. Figure 2 convinces that pulp has peculiar to its tissue components. Presence of odontoblastic tissue component, collagen fibers and blood microvessels although they appear in somewhat coarser form indicates in this. It may be explained by inability to prevent completely of autolytic processes during preparation of prepares (Fig. 2).
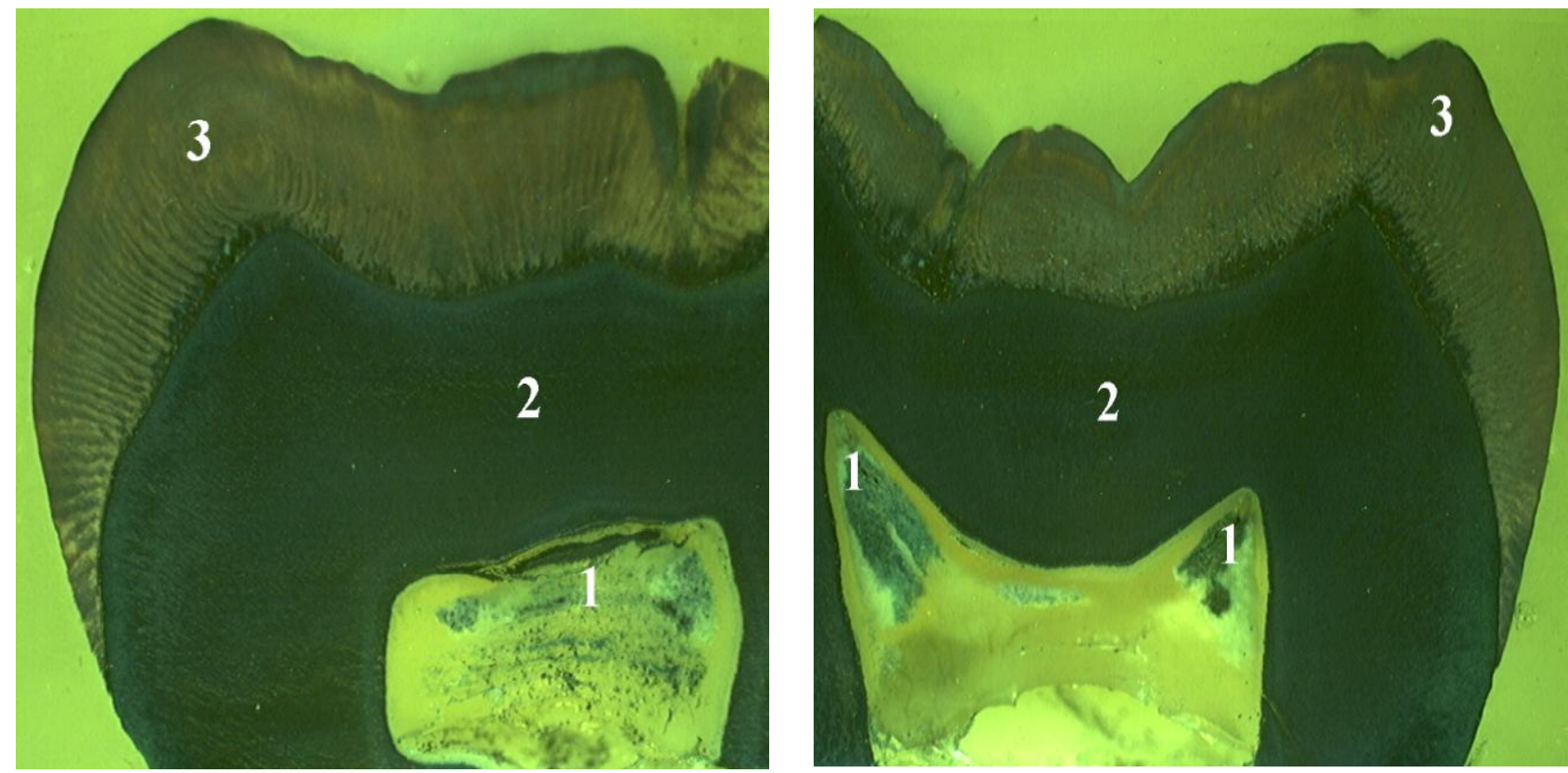

Fig. 1. Crown departments of two undamaged by caries third molars. Epoxy sections. Coloring by methylene blue. Lens 4 . 1 - petrificates in degenerative changed pulp; 2 - dentine; 3 - enamel.
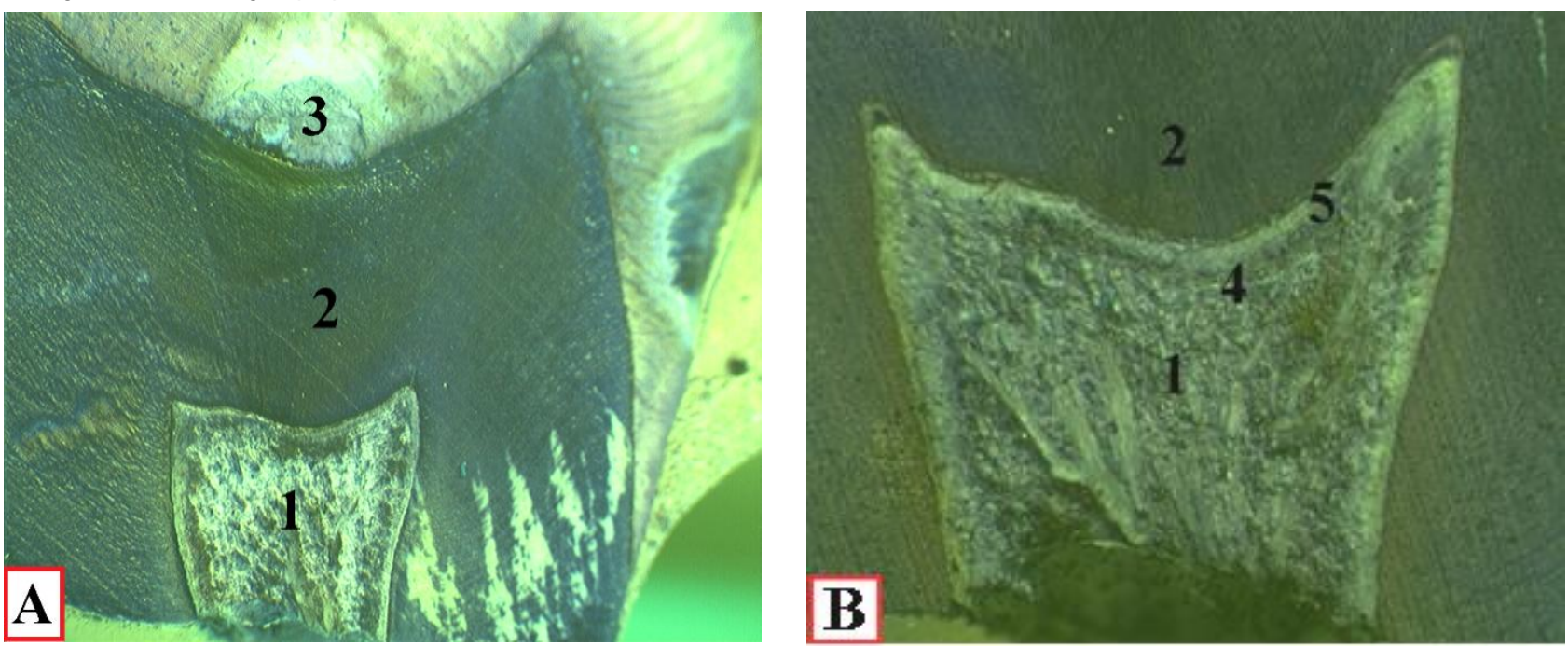

Fig. 2. Crown department of damaged by caries third molar. Epoxy sections. Coloring by methylene blue. A - lens 4. 5 - lens 7.1 - pulp; 2 - radial alteration of dentine; 3 - the center of carious destruction of enamel; 4 - layer of odontoblasts; 5 - predentine. 

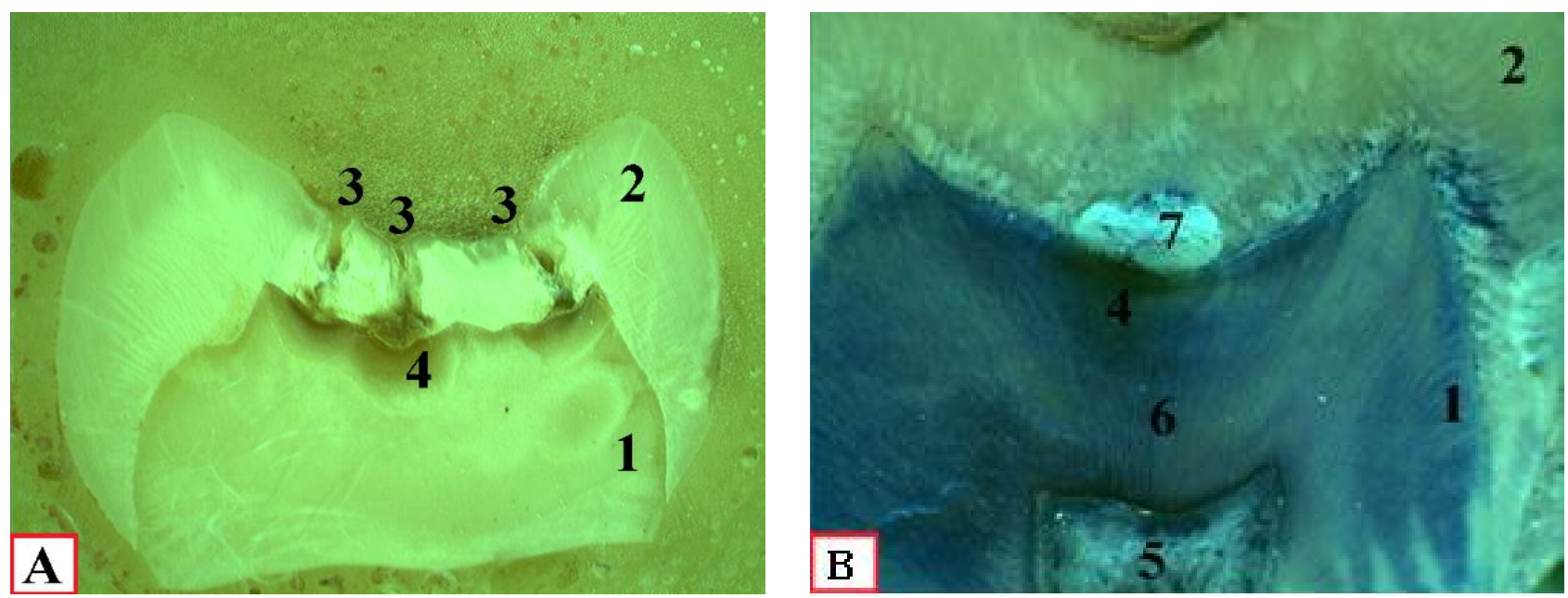

Fig. 3. Crown departments of external damaged by caries third molars. Epoxy sections. A - uncolored prepare, lens 2. Б - same prepare, colored by methylene blue. Lens 4 . 1 - dentine, 2 - enamel, 3 - grooves, 4 - dark pigmented dentin spots in the area of carious alteration of the enamel, 5 - pulp, 6 - radial alteration of dentine, 7 - carious damage of basal enamel.

During more attentive study we paid attention, which on some prepares in odontoblastic layer just opposite the carious alteration of the enamel, there is a noticeable compaction of the pulp (Fig. 3).

According to location of pigmented spot clearly was manifested destruction of deep layers of enamel. It should be noted that focuses of its carious alteration were located not only in region of grooves, but quite often they were manifested on side of the masticatory tubercles and lateral surfaces of the crown.

\section{Discussion}

Thus, in investigated by us intact teeth, pulp was manifested in condition of complete degeneration, reason of which unknown for us. But in this case we can refer to the literature, according to which development of pathological process in pulp should be considered from polyetiological positions [10, 12, 18, 21]. Herewith, the main link of its pathogenesis may be both external and internal factors, which cause loss of its caries-resistant properties, causing the pulpogenic mechanisms of caries development. This conception should be considered as important, because it force to pay attention on character of structural changes in tooth pulp in the beginning of the development of carious process, and it does not limit only with presence of external signs of damage of the enamel.

However, should be noticed that according to the thoughts of Yu.P. Kostylenko and I.V. Boiko [21] caries cannot damage enamel of teeth which for one reason or another it is non-available completely or it was prone to sclerosis, that is, no pulp - no caries. It also was confirmed by results of our research.

Pulp of carious third molars looks more full-fledged in comparison of their intact analogs. Thus, we want to say that in teeth which are prone to carious process, the pulp is in an active state. It means, it has all necessary reactogenic properties to change the antigenic composition of the hard tissues of the tooth, due to the influence of pathogenic microorganisms which occur in the grooves. Besides, this side of question about etiopathogenesis of caries is not as monosemantic as it seems at the first glance.

Due to the fact, that in the subodontoblastic layer of pulp, in opposite to the carious alteration of the enamel, locates exchange blood vessels, therefore it can be assumed that this consolidation occurred as result of infiltration of perivascular connective tissue, immunocompetent cells. The certainty of this assumption is proved by the fact that consolidation of the pulp and center of carious alteration projectively connect between each other with radial cord of alterative dentine known in literature as "dead tracts" [1, 10, 11, 12, 14, 19, 21, 31, 32]. According to thoughts of these authors which are based on the positions of modern immunology, in deep areas of the grooves under the influence of pathogenic microflora on organic components of basal enamel and superficial dentine occur creation of high active intermediate antigens (autoantigens) [9, 17, 21, 29, 33]. They are getting through the dentinal tubules into the pulp, cause activation of the local immune system, effector elements of which will cause the alteration of dental channels with the creation of "dead tracts" and further destruction of appropriate areas of enamel. Its damage may produce the new wave of antigen stimulation of immune reactions which cause the creation of antibodies that can react with antigen both damaged and intact enamel in connection with identity of separate specific determinant groups. This process accompanied by increasing of present damage, which cause new antigen galling. Thus, it is caused chain autoimmune (autoaggressive) process, which determines the pathogenesis of caries (carious disease).

In connection with this, it is impossible to leave without attention one very revealing morphological fact, which has 
not been taken into account by researchers in the study of the pathogenesis of caries before [3,21]. It means, that on the border with carious destruction, the consolidated spot of alterative dentine is located, a matrix of which has intensive brown pigmentation, which is very clearly visualized on unpainted epoxy sections (Fig. 3). It has the greatest intensity in the basal layer, where its compactness is decreasing and disappearing in the matrix of "dead tracts" of the dentine. Clearly pigmented spot on the border between dentine and enamel gives an opportunity to identify the hidden form of caries even on the simple sections of teeth without any coloration.

Results of our research don not give reasons to speak about exogenous nature of this pigmentation. However, today this phenomenon can be explained by that during caries, it occurs as the result of accumulation on the dentineenamel border of melanin which was created by the way of some metabolic transformations of tyrosine which is a product of phenylalanine - one of the amino acids in the protein substance of dentine $[4,16,21,24,30]$. Thus, there is reason to believe that this pigmentation of superficial dentine, which is located under the defect of enamel, is a result of storing of melanin which was created in the process of dystrophic dissociation of protein-carbohydrate complexes of the organic substance of the deep layers of dentine. Products of the metabolic transformations of phenylalanine achieve the superficial layer of dentine due to the centrifugal movement of the "dental fluid" along the dentinal tubules.

Clearly expressed morphological signs of carious damage of hard tissues, which are characterized by destructive changes look as radial "dead tracts" with their location from the pulp chamber to the damaged enamel, in its deep layers and creation of dark pigmented spots on the border with enamel indicate a latent form of caries.

In our view, the primary reason of the dystrophic changes in dentine with caries needs to find in the pulp. Thus, we want to say that teeth, which are prone to carious process,

\section{References}

[1] Arnold, W. (2013). Morphological analysis and chemical content of natural dentin carious lesion zones. Ann. Anat., 185(5), 419-424.

[2] Baume, L. J. (1980). The Biology of Pulp and Dentine. Ed.: Myers H.M.: Monographs in Oral science. Basel: Karger.

[3] Black, G. V., \& Blackwell, R. E. (1915). Some Observations on Mottled Teeth. Proceedings of the Pan-Pacific Dental Congress. San Francisco.

[4] Brookes, S. J., Berdal, A., Vieira, A. R., Babajko, S., \& Kirkham, J. (2018). Tooth Enamel: Frontiers in Mineral Chemistry and Biochemistry, Integrative Cell Biology and Genetics. Frontiers in Physiology, 9, 1153. https://doi.org/10.3389/ fphys.2018.01153

[5] Brusentsova, A. E., Peretyagina, I. N., \& Tishkov, D. S. (2016). Immunological status of dental pulp and its change in acute and chronic forms of pulpitis. Herald of New Medical Technologies, 23(2), 67-71. doi: 10.12737/20427 [ 6 ] Cawson, R. A., \& Odell, E. W. (2008). Cawson's Essentials of have the pulp in an active condition.

Thus, the above facts clearly indicate that hard tissues of third molars, which for one reason or another have degenerative changes in the pulp, are not prone to carious damage. Whereas, the pulp of carious teeth is in active condition, thus it has all need reactogenic properties for the changing of the antigen composition of the hard tooth tissues, so it has an influence on the development of the carious process.

There are reasons, to think that in the further development of the carious process, the pulp will be prone to complete necrosis, on which the destructive process of the hard tooth tissues will have stopped [11, 12, 21]. Practical conclusion: for the stopping of the carious process should be used depulping of the damaged tooth follows from it. But, it does not mean that it will stop a carious disease. It may include other teeth.

Pathomorphological connection between reactive changes in the pulp and carious damage of the enamel is alteration of the dentine which looks as radial "dead tracts". Thus, we pay attention to one important event which is characterized for carious damage, which consist in creation on the border with destructive enamel, dentine pigmented into brown color intensively. We think that destructive disintegration of protein-carbohydrates complexes of dentine with carious alteration which produces melanin lays at the base of this event. In our view, the study of this process can have determinant meaning in the knowledge of the etiopathogenesis of carious disease in which we see the further prospect of our research.

\section{Conclusions}

1. In teeth that are prone to carious process, the pulp is in an active state.

2. Hard tissues of the third molars with degeneratively altered pulp are not prone to carious lesions.

3. In order to stop the carious process in the tooth, it must be depulped.

Oral Pathology and Oral Medicine. 8-th ed. Edinburgh: Churchill Livingstone.

[7] Chen, X., Daliri, E. B.-M., Chelliah, R., \& Oh, D.-H. (2020). Isolation and identification of potentially pathogenic microorganisms associated with dental caries in human teeth biofilms. Microorganisms, 8(10), 1-12. doi: 10.3390/ microorganisms8101596

[8] Divaris, K., Fisher E. L., Shugars, D. A., \& White, Jr. R. P. (2012). Risk factors for third molar occlusal caries: A longitudinal clinical investigation. J. Oral Maxillofac. Surg., 70(8), 1771-1780.

[9] Enright, J. J., Friesell, H. E., \& Tresher, M. O. (1932). Studies of the cause and nature of dental caries. J. Dent. Res., 12, 759.

[10] Filenko, B. M. (2020). Etiopathogenetic parallels of morphological changes in chronic dental caries and its complications (literature review). Ukrainian Dental Almanac, 2, 40-46. ISSN: 2409-0255.

[11] Gasyuk, A. P., Kostyrenko, O. P., \& Nasonov, P. I. (2017). Morphogenesis of enamel caries. Ternopil Dental Summit: 
materials of the scientific-practical conference with international participation, dedicated to the 60th anniversary of the state higher educational institution "Ternopil State Medical University named after I.Ya. Gorbachev Ministry of Health of Ukraine"; Ternopil: Ternopil State Medical University. Available from: https://repository.tdmu.edu.ua/bitstream/handle/1/8513/ Conference\%20Proceedings\%20TDS.pdf?sequence=1\&isAllowed=y

[12] Gasyuk, P. A., Vorobets, A. B., Kostyrenko, O. P. \& Parfyonova, V. S. (2015). Morphogenesis of precariotic processes in enamel and dentin of large molars of a person. Mathematical Morphology: Electronic Metematic Biomedical Journal, 14(2), 1-8. ISSN: 1819-3730. Available from: http://sgma.alphadesign.ru/MMORPH/N-46-html/gasuk-2/gasuk-2.htm

[13] Gamzaev, B. M., Jafarova, A. R., Guseinova R. N., Abbasova R. A., Yusubova Sh. R., Alizade A. R., \& Ibragimova L. K. (2019). The role of the alkaline factor in the development of dental caries. Dentistry Problems, 15(4), 5-10. doi: 10.18481/ 2077-7566-2019-15-4-5-10

[14] Glinkin, V. V., Clemin, V. A., \& Glinkina, V. V. (2018). The relationship between the structure of the hard tissues of the tooth and the development of the carious process. In: G. Yu. Gulyaev, Innovative development of science and education: monograph. Penza: ICNS "Science and Education". ISBN: 9785-907046-54-2

[15] Grintsova, N. B., Vasko, L. V., Kiptenko, L. I., \& Gortinskaya, O. M. (2017). Histological structure of the organs of the oral cavity. General principles of structural organization of the oral mucosa: a textbook. Sumy: Sumy State University. ISBN: 978-966-657-651-7

[16] Jenkins, G. R. (1978). The Physiology and Biochemistry of the Mouth. 4th ed. Oxford.

[17] Heigetyan, A. V., Bragin, E. A., Maksyukov, S. Yu., Labushkina, A. V., Alutina, E. V., \& Kharseeva, G. G. (2015). Immunological parameters in patients with caries of the contact surfaces of the lateral teeth. Clinical Laboratory Diagnostics, 8, 52-54.

[18] Khomenko, L. O., Bidenko, N. V., Ostapko, O. I., Golubeva, I. M., Sorochenko, G. V., \& Trachuk, Yu. M. (2013). Tooth decay control: evolution concept. Dentistry: From Science to Practice, 1, 53-65.

[19] Kidd, E. A. M., \& Fejerskov. O. (2004). What constitutes dental caries? Histopathology of carious enamel and dentine related to the action of cariogenic biofilms. J. Dent. Res., 83, 35-38.

[20] Kostilenko, Y. P., \& Boyko, I. V. (2004). A method of making preparations for intravital preserved teeth for multipurpose research. Clinical Anatomy and Operative Surgery, 3(2), 6365. ISSN: $1727-0847$

[21] Kostilenko, Y. P., \& Boyko, I. V. (2007). Enamel Structure and the Problem of Caries: monograph. Poltava. ISBN: 978-9668716-06-5

[22] Kostylenko, Yu. P., Starchenko, I. I., Pryluky, O. K., \& Boyko, I. V. (2012). VDNZU "Ukrainian Medical Dental Academy", patent owner. Method of Placing Biological Tissues in Epoxy Resin for Macro-microscopic Studies. Utility model patent G01N1/ 00.4201201052

[23] Marsh, P. D. (2004). Dental plaque as a microbial biofilm. Caries Res., 38, 204-211.

[24] Mikaelyan, N. P., \& Komarov, O. S. (2019). Biochemistry of Oral Cavity Hard Tissues in Health and Disease. Moscow. ISBN: 978-5-7974-0574-0

[25] Mira, A., Simon-Soro, A., \& Curtis, M. A. (2017). Role of microbial communities in the pathogenesis of periodontal diseases and caries. J. Clin. Periodontol., 44, 23-38.

[26] Moscowsky, A. V., Lyubovtseva, L. A., \& Shumsky, A. V. (2008). Clinical Morphology and Immunology of the Dental Pulp. Cheboksary: Publishing house of the Chuvash University.

[27] Moscowsky, A. V., Urukov, Y. N., Viktorov, V. N., Voropaeva, L. A., Lezhenina, S. V., Moskovskaya, O. I. ... Tsyganov, V. P. (2018). The role of tissue basophils in the regulation of the neurotransmitter status of the dental pulp in health and disease. Medical Almanac, 53(2), 51-53.

[28] Rosebury, T. (1933). The problem of dental caries. Archives of Pathol., 15, 260.

[29] Shinkevich, V. I., \& Kaidashev, S. P. (2019). The contribution of macrophages to the pathogenesis of chronic periodontitis in humans and research prospects. Literature review. Zaporozhye Medical Journal, 21(1(112)), 137-143 doi: 10.14739/2310-1210

[30] Sirak, S. V., Shchetinin, E. V., Kobylkina, T. L., Adamchik, A. A., Sirak, A. G., \& Vafiadi, M. J. (2016). Histochemical features of reparative dentinogenesis of the dental pulp. Russian Dental Journal, 20(6), 301-304. doi: 10.18821/1728-2802

[31] Tkachenko, I. P., Brailko, N. N., Kovalenko, V. V., Nazarenko, Z. Yu., \& Sheshukova, O. V. (2018). Morphological examination of enamel and dentin of teeth with a carious process and non-carious lesions. Wiadomosci Lekarskie, LXXI(5(II)), 10011005.

[32] Tkachenko, I. M., \& Kovalenko, B. B. (2017). Morphological and Chemical Examination of Tooth Enamel and Dentin with Increased Abrasion and Caries. Modern methodology of science and education. Warsaw, Poland: Warsaw.

[33] Veiga, N., Aires, D., Douglas, F., Pereira, M., Vaz, A., Rama, L. ... Bexiga, F. (2016). Dental caries: A review. Journal of Dental and Oral Health, 2(5), 1-3. ISSN: 2369-4475

\section{МОРФОЛОГІЧНИЙ СТАН ПУЛЬПИ ІНТАКТНИХ ТА УРАЖЕНИХ КАРІЄСОМ ТРЕТІХ МОЛЯРІВ}

Костиленко Ю.П., Талаш Р.В., Білаш С.М., Бойко І.В., Буханченко О.П., Іваницька О.С.

На сьогоднішній день існує теорія про те, що підвищення стійкості до карієсу спостерігається у тих зубів, у яких з тих чи інших причин відбулися деструктивні зміни в пульпі. Саме тому виникла необхідність вивчення впливу життєдіяльності пульпи на розвиток каріозного процесу. Мета роботи - вивчити мікроскопічну будову епоксидних шліфів інтактних і уражених карієсом третіх молярів. Були вивчені 4 інтактних і 6 уражених карієсом третіх молярів. Для цього виготовляли препарати з урахуванням вільного проникнення в пульпу розчину фріксатора. 3 цією метою відразу ж після видалення зуба ми вдавались до відсікання його коренів майже біля коронки, зберігаючи иілісність останньої. Методика полягала в просочуванні препаратів епоксидною смолою, заідно з методом епоксидної пластинації препаратів зубів, розробленим на кафедрі анатомії людини Української медичної стоматологічної академії. Епоксидні блоки розсікали диском навпіл до оголення твердих тканин коронки зубу разом із пульпою. Встановлено, що тверді тканини (дентин і емалеве покриття) інтактних третіх молярів не мали будь-яких структурних вад. Разом із тим, вміст їх пульпової камери представляв собою, в основному, аморфну речовину, позбавлену будь-яких типових для пульпи тканинних структур. Тобто, пульпа виявлялась в стані повного переродження. Зовсім протилежну картину представляли собою препарати каріозних зубів. Виявлено, що в їх пульповій камері містились цілком помітні, типові для зубної пульпи, тканинні структури. Примітно, що в субодондонтобластичному 
шарі, навпроти каріозної альтерації емалі, має місце ущільнення пульпи, яке може бути обумовлено інфільтрацією периваскулярної сполучної тканини імунокомпетентними клітинами. Встановлено, що на межі з каріозною деструкцією емалі знаходиться ущільнена пляма альтерованого дентину, матрикс якого інтенсивно пігментований в коричневий колір, за рахунок накопичення на дентино-емалевій межі меланіну. Надмірне його утворення асоціюється з деструкцією білкововуглеводних комплексів органічної речовини глибоких шарів дентину. Нами встановлено, що ущільнення пульпи і вогнище каріозної альтерації емалі проєктивно зв'язані між собою променеподібним тяжем альтерованого дентину, відомого в літературі під назвою "мертвих трактів". Отже, є підстави вважати, що виявлені зміни свідчать про приховану форму карієсу, з пульпогенним механізмом розвитку. Таким чином, можна стверджувати, що зуби, у яких з тих чи інших причин сталися дегенеративні зміни пульпи, не схильні до каріозного ураження, тоді як у каріозних зубах пульпа знаходиться в активному стані і залучена до патогенезу каріозного процесу.

ключові слова: карієс, треті моляри, епоксидний шліф, емаль, дентин, пульпа. 